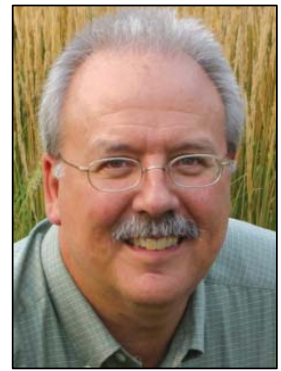

\author{
METRICS FROM THE FIELD \\ Blending insights from research with insights from practice \\ Ken Meter
}

\title{
Learning how to multiply
}

Published online 24 January 2011

Citation: Meter, K. (2011, January). Learning how to multiply. Journal of Agriculture, Food Systems, and Community Development, 1(2): 9-12.

doi:10.5304/jafscd.2010.012.014

Copyright (C) 2011 by New Leaf Associates, Inc.

As I work across the country, I often get asked by local economic officials, or potential investors, what the economic impact would be if investments were made in community-based food activity.

This seems like one of the right questions to ask, but it is typically asked for the wrong reasons. First of all, in most communities the economic impact can be estimated fairly easily by knowing the amount of locally produced food that will be consumed by local people. Typically, especially when few firms are locally owned, all that is needed is to multiply these sales figures by 1.3 to get a reasonable minimum estimate of overall impact This is a typical multipler measurement in an

Community groups and local governments often spend money needlessly trying to conform to the wishes of developers and political leaders, rather than being able to set the terms of the development discussion to address local food visions. One of the key issues is the calculation of an economic multiplier for proposed projects. In this column, Ken Meter offers some perspectives from his work with local officials on how to frame the multiplier issue, and how simpler estimates might be calculated. industrial farm community. A tribal reservation might be much lower, 1.1 or less.

I wince as people spend thousands of dollars to obtain a more elaborate value, including the number of jobs or new local sales revenue, that would be generated. As a former planning commissioner in my home town, I understand that these calculations are the currency around which

\footnotetext{
Ken Meter is president of Crossroads Resource Center in Minneapolis, Minnesota. He has performed 56 local food-system assessments in 23 states and one Canadian province; this information has promoted effective action in partner communities. He served as coordinator of the review process for USDA Community Food Project grants, and has taught economics at the Harvard Kennedy School and the University of Minnesota. He is co-convener of the Community Economic Development working group of the Community Food Security Coalition. A member of the American Evaluation Association's Systems Technical Interest Group, Meter also serves as an Associate of the Human Systems Dynamics Institute. He serves as a contributing advisor to JAFSCD.
} 
local investment decisions are often made. The software that generates them is sound. Yet they are seldom satisfying totals.

An economic multiplier is a measure of how many times a dollar earned in one community cycles through that locale before it leaves. Strictly speaking, a multiplier only applies to a specific firm doing business in a specific context. If economic transactions cycle wealth back into the community, amplifying the local purchases made by a local business, the multiplier will be high. At minimum, as typically calculated, a multiplier must be 1.0. This means that each dollar a given business earns leaves the community immediately. If the multiplier is 2.0, this means that for each dollar earned, an additional dollar cycles through the locale - a total of two dollars. The larger the multiplier, the more a proposed investment might impact a local economy.

What such numbers do is lubricate a political process that wants to think in the short term and consider only short-term impacts. Civic official X can get in front of the cameras and say, "By investing $\mathrm{Y}$ dollars, we will generate $\mathrm{Z}$ jobs in our community." Then attention shifts to the next project. Seldom does anyone do the research to find out whether those jobs were created, or whether they lasted.

Moreover, as one economic development official pointed out to me, local foods businesses are "small potatoes" compared to the more favored investments: housing projects and manufacturing plants.

The trouble with this line of reasoning is revealed in other, nonmultiplier studies. When American Farmland Trust measured the actual net tax base created by building new suburban housing, it discovered that the costs of public services typically exceeded the new tax base that was created: that is, new housing is typically a losing proposition for the municipality's long-term tax base.

Increasingly, I find economic developers saying they invested in factories only to find that once the incentives were used up, the factory moved to a different state or nation, because it got incentives (or cheaper labor) in its new location.

After the official who considered local foods initiatives to be tiny tubers offered his opinion, someone in the room had the courage to point out that few housing and factory deals were being made in these times. He agreed. A year later, he had lost his job, presumably because he had not convincingly shown the county that it needed a development officer during a time when no deals were being made.

Listening more closely to local food proponents might have made his job more secure. Even though he would have seen little short-term payoff, his efforts to work with his own citizens would have built the foundation for a stronger local economy.

The New Economics Foundation in the UK has done a fine job of demystifying the concept of the economic multiplier in its development of the "Local Multiplier 3." NEF argues that about 90\% of the economic multiplier is defined by the first three cycles of cash through a given locale. This includes: (a) how much the firm sells to the local community, (b) how many locally produced inputs the firm purchases from local suppliers, and (c) how many locally sourced products the firm's employees buy. NEF's book The Money Trail outlines this case quite eloquently, and offers pragmatic calculation templates for resident groups to use (Sacks, 2002). The main limitation I see is that apparently it is easier in the UK to get firms to divulge their financial figures than it is in the U.S. It is difficult to do citizen multiplier calculations without these data.

The multiplier is, then, a fairly easy concept to grasp. It is a measure of the economic infrastructure that surrounds a given business. If the infrastructure connects local economic actors and promotes local trade, the multiplier gets larger. This means that the more connected a community is to itself, and the more local businesses trade with each other, and the longer a given dollar will linger 
in the community. Geography plays a role: the larger the land base, in general, the more a dollar can multiply, since more hands are likely to be involved in trade. Of course, it also matters that local residents decide to buy from local stores. Even more importantly, they should buy locally produced items. Heading to the local vendor to buy an item that was produced in China does not do a great deal to improve the local economy.

Some examples bear this out. A Michigan study found a statewide multiplier of 1.32 for produce raised on medium-sized family farms (Conner, Knudson, Hamm, \& Peters, 2008). For the state of Iowa, it was calculated that dollars spent at the state's farmers' markets cycled more, attaining a multiplier of 1.58 (Otto \& Varner, 2005). Another Iowa economist found that a small restaurant that had committed itself to buying local foods generated a multiplier of 1.9 in an eight-county area, as compared to a value of 1.53 for an average restaurant in the region (Swenson, 2007). An Oregon study indicated that each dollar spent buying food for school lunches cycled enough to create a multiplier of 1.87 in the state (Ecotrust, 2009). In one small-farm region of western Wisconsin, the overall output multiplier was calculated between 2.2 and 2.6 (L. Swain, ${ }^{1}$ personal interview, February 12, 2001; Swain, 1999; Swain \& Kabes, 1998).

What characterizes the places with large multipliers is social capital (or social connectivity): these are communities whose residents trade among themselves because they are connected with each other. The industrial economy is precisely what breaks down these local connections, by forcing consumers to rely on distant suppliers and by creating jobs instead of liveliboods — with the result that local residents feel they have less stake in shaping local policy, and often end up in fact having very little influence. Those civic officials who, raising the question posed at the opening of

\footnotetext{
${ }^{1}$ Economics professor Larry Swain, community development specialist for the University of Wisconsin Extension Service and director of the Survey Research Center at UW-River Falls (now retired).
}

this essay, hold off on investing in a new project because the multiplier is too low, will find it never gets large enough.

I have been arguing for several years now that investing in community-based foods is one of the best ways we have for building local economies and local multipliers. This is not because the shortterm rewards are great, but because forming community foods networks is one of the best ways I can think of to build local commerce and local business ownership. After all, food is the number two household expense after housing. Consumer food purchases total US $\$ 1$ trillion per year, more than enough to have financed the bank stimulus package a few years back. Moreover, we all eat, and we make decisions about what to eat, three times a day. Everyone gets involved in this discourse.

Food also has less need for startup capital. One can begin farming at a small scale and produce healthy food to eat without a great deal of investmentalthough clearly it may take substantial public and private capital to actually make a good living. Yet if a community wants to make windmills, solar collectors, factories, or banks, the entry costs are much steeper.

Primarily, however, food is a very special product. It forces us to create a more inclusive economy. If someone cannot afford food, we cannot simply say they are "out of the market." To do so would be cruel, since food is a human right. More pragmatically, it is likely that someone who does not eat well will get ill—and will often require medical attention they also cannot afford, provoking additional public expense. Since county governments are often on the hook for caring for people with no health insurance, some counties could find themselves saving hundreds of millions of dollars by building local food trade that ensures residents eat the healthiest meals possible. This can reduce the erosion of resident assets.

This work of creating a community food economy, however, is long term, and our political process is notorious for being unable to handle long-term discussions. The reason that planning for the long 
term pays off is well documented by Robert Putnam, author of Bowling Alone and a pioneer in the measurement of social capital. In Making Democracy Work, he shows that the regions of Italy with the strongest democracies are also those that had the strongest craft guilds in the 1300s.

The proper question to ask of developers, it seems to me, is, "How do we best build a local multiplier?" The answer is community foods. With a time frame like this, it is high time we get started.

\section{References}

Conner, D. S., Knudson, W. A., Hamm, M. W., \& Peters, H. C. (2008, December). The food system as an economic driver: Strategies and applications for Michigan. Journal of Hunger \& Environmental Nutrition, 3:4, 371-383. doi:10.1080/19320240802528849

Ecotrust. (2009, March 18). Farm to school investment yields a healthy return into state coffers. Accessed at http://www.ecotrust.org/press/f2s investment 20 090318.html
Otto, D., \& Varner, T. (2005, March). Consumers, vendors, and the economic importance of Iowa farmers' markets: $A n$ economic impact survey analysis. Iowa State University: Leopold Center for Sustainable Agriculture and its Regional Food Systems Working Group, part of the Value Chain Partnerships for a Sustainable Agriculture, Report RWG03-04. Accessed at http://www.leopold.iastate.edu/research/ marketing files/markets rfswg.pdf

Sacks, J. (2002). The Money Trail: Measuring your impact on the local economy using LM3. London: New Economics Foundation. Available at http://www.neweconomics.org

Swain, L. B. (1999). A study of the economic contribution of small farms to communities-completed 1996 to 1999. Unpublished manuscript.

Swain, L. B., \& Kabes, D. (1998). 1996 community supported agriculture report. Unpublished manuscript.

Swenson, D. (2007, March). Economic impact summaries for local food production. Iowa State University: Leopold Center for Sustainable Agriculture, and University of Northern Iowa Center for Energy and Environmental Education. See K. Enshayan (2008) summary listed at http://www.leopold.iastate.edu/ research/marketing_files/food/food.htm 